J. Product. \& Dev., 21(3): 349-367 (2016)

\title{
RESIDUES OF THIAMETHOXAM AND CHLORPYRIFOS ON OKRA IN RELATION TO THEIR EFFECTS ON SOME INTERNAL QUALITY PARAMETERS AND ELEMENTS IN FRUITS.
}

Shalaby A. Aly

Plant Protection Department, Faculty of Agriculture, Zagazig University, Egypt

\section{ABSTRACT}

The present work was conducted to study the residues of two insecticides on okra plant. Thiamethoxam (Actara 25\% WG) and chlorpyrifos (Dursban 48\% EC) were sprayed at mature stage. Fruits and leaves samples were collected at 2 hrs to 15 days after application. QuEChERS method was used for extraction and clean-up and analyzed using HPLC and GC for thiamethoxam and chlorpyrifos, respectively. Results revealed that, okra leaves remained higher initial amounts than fruits by about $382.52 \%$ and $893.48 \%$ of thiamethoxam and chlorpyrifos, respectively. Loss percentages of initial deposits were higher in okra fruits than leaves. The half-life $\left(t_{1 / 2}\right)$ values of thiamethoxam and chlorpyrifos were 2.09, 3.16 and 1.59, 2.57 in okra fruits and leaves, respectively. Data indicated that okra fruits could be consumed safely after 15 days of treatment with thiamethoxam, washing or boiling of okra fruits ( 2 min) during the first 6 days after spraying did not alter the PHI value, while in case of chlorpyrifos washed and unwashed okra fruits could be used safely after 6 days and no safety interval was needed after boiling okra fruits for $2 \mathrm{~min}$. The removal percentages of thiamethoxam and chlorpyrifos residues by washing ranged between 9.39 - 46.23\%; $5.88-21.40 \%$, while the corresponding values due to boiled the okra fruits 2 min ranged from 74.77 to $89.09 \%$; 84.63 - 87.51\%. Residues of thiamethoxam and chlorpyrifos significantly decreased total soluble sugar\%, glucose $\mathrm{mg} / 100 \mathrm{~g}$, acidity \%, total soluble solids \%, ascorbic acid $m g / 100 g$, protein content $\%$, $\beta$-carotene $\%$, protein $\%$ and dry matter $\%$ of fresh treated okra fruits comparing with the control during the tested period. Concerning the trace / nutrients elements thiamethoxam significantly reduced the mean values of $\mathrm{N} \%, \mathrm{P} \%, \mathrm{~K} \%, \mathrm{Mn} \%$ and $\mathrm{Ca} \%$ and increased the mean amounts of $\mathrm{Fe} \%$ and $\mathrm{Zn}$ in treated okra fruits. 
Chlorpyrifos significantly reduced the mean levels of $\mathrm{N} \%, \mathrm{P} \%, \mathrm{~K} \%, \mathrm{Fe} \%$ and $\mathrm{Ca} \%$ and increased the mean amounts of $\mathrm{Mn \%}$ and $\mathrm{Zn}$ in okra fruits. These effects were more pronounced in thiamethoxam treatment. Therefore, attention must be given to the use of thiamethoxam especially during the mature stage.

Conclusively, okra fruits treated with the neonicotonoied insecticide thiamethoxam needed a long interval to reach the maximum residue limits. Also, obtained data revealed that its residues were more effective in some quality attributes as well as some trace and nutrient elements than that the organphosphorus chlorpyrifos. Therefore, special care must be given to the use of this insecticide especially at the mature stage of okra plants.

Key words: Thiamethoxam, chlorpyrifos, QuEChERS, okra, residues, quality parameters.

\section{INTRODUCTION}

In the ancient time, Egyptian farmers cultivated other plants such as okra, squash and onion either between or adjacent of the main crops (cotton fields). Such vegetable crops are exposed directly or indirectly to drifts of pesticides recommended against pests infesting the main crop. This intercropping system results in undesired residues onto the Non-target crops, i.e, the vegetable ones which had deleterious effects on consumes.

Nowadays, farmers cultivated okra plants separately in vast areas due to economical return. In Egypt, Okra is one of the most popular vegetable summer crops. It has been used for its young green pods as fresh, canned, frozen and dry states. Okra fruit has high nutritional value. It contains vitamin A, B and C as well as fat, carbohydrate, fiber, iron, iodine and is a protein source in nearly all developing countries. Its fruits contain a small amount of $\mathrm{Ca}, \mathrm{P}, \mathrm{Mg}$ and $\mathrm{K}$. (Grubben and Denton, 2004). Okra plants are liable to be infested with different insect pests (jassid, aphids, whiteflies, cotton leaf worm and spider mite) causing serious injury and reducing the green okra fruits ( Mahal et al., 1994; Sattler et al., 2007 and Amro et al , 2013). So pest control is necessary and played a significant role in adequate production. Many agricultural pests were controlled with insecticides in extensively way. Insecticides were used especially at fruiting stage with non safe waiting period therefore, leads to 
accumulation of pesticide residues in consumable vegetables. (Kumari et al., 2002).

Thiamethoxam is systemic neonicotinoied insecticide for soil and foliar application, used to control a variety of pests such as aphids, whiteflies, trips, beetles, leafhopper, bugs and borers in fruiting, corn, tubers, vegetable and cotton (Antunes-kenyon and Kennedy, 2001). Many studies have reported excellent efficacy of thiamethoxam against sucking insect pests such as aphids, trips or leafhopper via contact and ingestion at low rates (Manson et al. 2000, Bethke et al., 2001).

Chlorpyrifos was used to control of Coleoptera, Diptera, Homoptera and Lepidoptera in soil or on foliage in over 100 crops, including some vegetables and field crops. Chlorpyrifos was non-systemic insecticide with contact, stomach, and respiratory action (MacBean, 2012).

Therefore, the main objective of this study was to evaluate the residues of thiamethoxam and chlorpyrifos in okra fruits and leaves, and their effects on some chemical constituents and quality attributes. Effects of washing with tap water and boiling to removal their residues from treated okra fruits were also studied.

\section{MATRIALS AND METHODS}

\section{1- Pesticide selected for this study:}

In this work, pesticides used and their rates per feddan $(1$ feddan $=4.200$ $\mathrm{m}^{2}$ ) were thiamethoxam, (Actara $25 \% \mathrm{WG}$ ) at $80 \mathrm{~g} /$ feddan and chlorpyrifos, (Dursban $48 \%$ EC) at $1 \mathrm{~L} /$ feddan. Rates of pesticideal application were chosen on the basis of recommended rates on other related crops.

\section{2- Field experiment and sampling}

The research was conducted in summer season of 2016 at private field of okra (Abelmoschus esculentus L. ver baladey) located at El-Tahra village, Zagazig district, Sharkia governorate.

The experiments were planned in a randomized complete block design. For each tested insecticide, three plots were done $(6 \times 7 \mathrm{~m}$ each) and plot to plot distance $2 \mathrm{~m}$. A knapsack-sprayer with one nozzle was used to deliver 200 liters water/ feddan. Mature plants were sprayed (June 15, 2016) with thiamethoxam and chlorpyrifos once at the rate of $20 \mathrm{~g}$ a.i. / feddan, $480 \mathrm{~g}$ a.i. / feddan, respectively. The control plots were left unsprayed. Samples (fruits and leaves) 
were taken after $2 \mathrm{hrs}, 1,3,6,9,12$ and 15 days. Also, fruit Samples, $2 \mathrm{hrs}, 1,3$ and 6 days, were subjected to study the effect of washing and boiling on pesticide residues. In this set treated okra fruits were divided in two subsamples, the first was washed with tap water and the second was boiled for 2 minute then left to cold at room temperature.

\section{3- Residues determination}

Okra samples were extracted and cleaned up using QuEChERS methodology (Anastassiades et al., 2003). A homogenized okra fruit and leaves samples $(10 \mathrm{~g})$ was taken in to a centrifuge tube $(50-\mathrm{mL})$. Fifteen milliliters of acetonitrile containing $1.0 \%$ acetic acid was transferred to the centrifuge tube and vigorously shaken for $1 \mathrm{~min}$. Then, $4 \mathrm{~g}$ magnesium sulfate anhydrous, $1 \mathrm{~g}$ sodium acetate was added, and then the mixture was shaken vigorously for 5 min. The mixture was centrifuged at $3000 \mathrm{rpm}$ for $5 \mathrm{~min}$. One milliliter of the supernatant was transferred to centrifuge tube $(1 \mathrm{ml})$ and shaken with $50 \mathrm{mg}$ primary secondary amine (PSA), $10 \mathrm{mg}$ graphitized carbon black and $150 \mathrm{mg}$ magnesium sulfate. Thereafter, the tube was centrifuged for $10 \mathrm{~min}$ at 6000 rpm. The supernatant of thiamethoxam was taken for analysis by HPLC with an Agilent 1260 HPLC system (USA), with quaternary pump, auto sampler injector, thermostat compartment for the column, and photodiode array detector. The chromatographic column was Zorbax $\mathrm{C}_{18} \mathrm{XDB}(250 \times 4.6 \mathrm{~mm}, 5$ $\mathrm{mm})$. The column was kept at room temperature. Flow rate of mobile phase (acetonitrile / water, 90:10, v/v) was $1 \mathrm{ml} \mathrm{min}^{-1}$, and injection volume was $20 \mu \mathrm{L}$.

The supernatant of chlorpyrifos was taken for analysis by Agilent Technologies 7890A gas chromatograph equipped with flame photometric detector (FPD) operated in the phosphorus mode (526 nm filter) was used for the determination of chlorpyrifos residues. The column was HP-5 (30 m×0.32 $\mathrm{mm} \times 0.25 \mu \mathrm{m}$ film thickness) $5 \%$ diphenyl and 95\% dimethylpolysiloxane. Injector temperature was $250{ }^{\circ} \mathrm{C}$. Detector temperature was $250{ }^{\circ} \mathrm{C}$. Column temperature was $220{ }^{\circ} \mathrm{C}$ for chlorpyrifos. Gases flow rates were 60,30 and 30 $\mathrm{ml} / \mathrm{min}$. for nitrogen, hydrogen and air, respectively (Hegazy et al., 2006). These conditions resulted in good separations and high sensitivity was obtained with retention time $3 \mathrm{~min}$ and $2.2 \mathrm{~min}$ for thiamethoxam and chlorpyrifos, respectively. 


\section{4- Effect of thiamethoxam and chlorpyrifos residues on some quality parameters and trace elements}

To study the effect of thiamethoxam and chlorpyrifos residues on some quality parameters and some trace and nutrient elements, samples of treated and untreated tomato fruits were taken at 9, 12 and 15 days after application. Quality parameters included total soluble sugars, glucose, acidity, total soluble solid, ascorbic acid, $\beta$-carotene, protein and dry matter. While the elements $\mathrm{N}$, $\mathrm{P}, \mathrm{K}, \mathrm{Fe}, \mathrm{Mn}, \mathrm{Ca}$ and $\mathrm{Zn}$ were also determined.

Nitrogen, potassium and phosphorus were determined by the method of Evenhuis et al., (1980). Calcium, manganese, iron and zinc were determined by atomic adsorption spectroscopy (Jackson, 1967). Total soluble sugars and glucose were determined colorimetrically using the picric acid method as described by Dubois et al., (1956). Total soluble solid were estimated using a refractometer. Acidity, ascorbic acid, protein and dry matter were determined according to the Methods of Association of Official Analytical Chemists (AOAC) (1984). $\beta$-carotene was determined by the method of Ben-Amotza and Avron (1983).

\section{Recovery samples and statistical analysis}

To estimate the recovery percentages, known quantities of thiamethoxam and chlorpyrifos were added to control samples of okra fruits and leaves at levels of 0.1 and $1 \mathrm{mg} / \mathrm{kg}$ extract and clean-up were carried out as described above. The recovery rates in fruits and leaves for the two tested insecticides were $90.18 \%$ and $88.15 \%$ in leaves and fruit for thiamethoxam, respectively and the respective values for chlorpyrifos were 94.82 and $85.73 \%$. The all results obtained were corrected according to their recovery percentages.

Statistical significance of the data was determined by using the analysis of variance with L.S.D method at the probability of 0.05 Steel and Torrie (1980). The rate of degradation $(\mathrm{K})$ and Half-life $(\mathrm{t} 1 / 2)$ periods of each insecticide were calculated according to (Gomaa and Belal, 1975).

\section{RESULTS AND DISCUSSION}

\section{1- Residues of thiamethoxam in and on okra fruits and leaves}

Residues and loss percentages of thiamethoxam in and on okra fruits and leaves were illustrated in Table (1) and Figure (1). The initial deposits, 
Table 1: Residues of thiamethoxam detected in okra fruits and leaves.

\begin{tabular}{|c|c|c|c|c|c|c|}
\hline $\begin{array}{c}\text { Days after } \\
\text { treatment }\end{array}$ & $\begin{array}{c}\text { Fruits } \\
\text { residues } \\
(\mathbf{m g} / \mathbf{k g})\end{array}$ & $\begin{array}{c}\text { Dissipation } \\
\mathbf{\%}\end{array}$ & Persistence & $\begin{array}{c}\text { Leaves } \\
\text { residues } \\
(\mathbf{m g} / \mathbf{k g})\end{array}$ & $\begin{array}{c}\text { Dissipation } \\
\mathbf{\%}\end{array}$ & Persistence \\
\hline $\begin{array}{c}\text { Initial } \\
(2 \mathrm{hrs})\end{array}$ & 0.532 & - & 100.00 & 2.035 & - & 100.00 \\
\hline 1 & 0.393 & 26.13 & 73.87 & 1.665 & 18.18 & 81.82 \\
\hline 3 & 0.218 & 59.02 & 40.98 & 1.072 & 47.32 & 52.68 \\
\hline 6 & 0.130 & 66.92 & 33.08 & 0.864 & 57.54 & 42.46 \\
\hline 9 & 0.034 & 91.35 & 8.65 & 0.392 & 80.74 & 19.26 \\
\hline 12 & 0.014 & 96.43 & 3.57 & 0.115 & 93.09 & 6.91 \\
\hline 15 & 0.003 & 99.41 & 0.56 & 0.082 & 95.07 & 4.93 \\
\hline $\mathrm{K}$ & \multicolumn{7}{|c|}{0.331632} & & & 0.218785 & \\
\hline $\mathrm{t} \mathbf{2} 2$ & 2.09 & & \multicolumn{3}{|c|}{3.16} \\
\hline
\end{tabular}

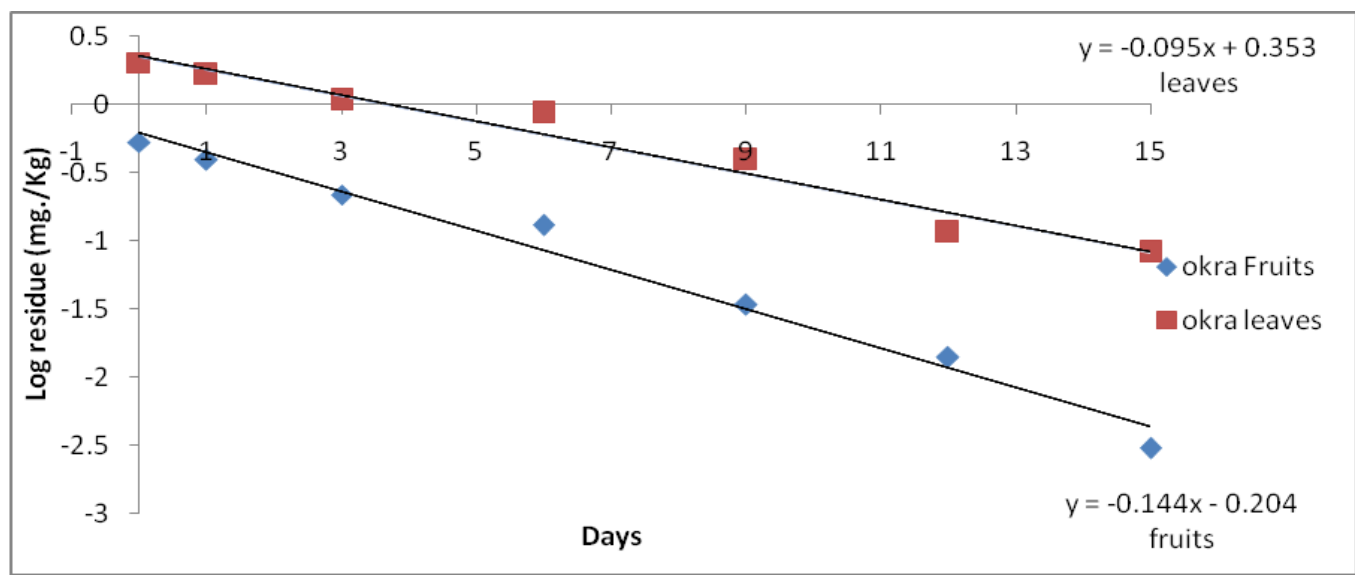

Figure 1: Log. residue - day regression line of thiamethoxam in okra fruits and leaves.

which remained on okra fruits and leaves two hours after treatment were 0.532 $\mathrm{mg} / \mathrm{kg}$ and $2.035 \mathrm{mg} / \mathrm{kg}$, these amounts dropped to $0.393 \mathrm{mg} / \mathrm{kg}$ and $1.665 \mathrm{mg}$ $/ \mathrm{kg}$ one day after the application indicating a dissipation rate of $26.15 \%$ and $18.18 \%$, respectively. Residues of thiamethoxam in and on okra fruits and leaves were gradually decreased to $0.218,1.072 ; 0.130,0.864 ; 0.034,0.392$; 
$0.014,0.105$ and $0.003,0.022 \mathrm{mg} / \mathrm{kg}$ indicated loss rates of 59.02, 47.32; 66.92, $57.54 ; 91.35,80.74 ; 96.43,94.85$ and $99.44,98.92 \%$, respectively after $3,6,9$, 12 and 15 days of spraying. The $t_{1 / 2}$ values were 2.09 and 3.16 days from the treatment with degradation rates of 0.331632 and 0.218785 for the okra fruits and leaves, respectively. These figures indicated that the insecticide thiamethoxam was degraded higher in fruits than that leaves.

Data in the same table indicated that despite of the low $t_{1 / 2}$ for thiamethoxam in fruits (2.09 days) okra fruits were consumed safely after 15 days of treatment, concerning health aspects, the maximum residue limit (MRL) of thiamethoxam residues in and on okra according of EU Pesticides database - European Commission was $0.01 \mathrm{mg} / \mathrm{kg}$. This may be due to the dangers effect of thiamethoxam for mammalian.

\section{2- Residues of chlorpyrifos in and on okra fruits and leaves}

Residues and loss percentages of chlorpyrifos in and on okra fruits and leaves were shown in Table (2) and Figure (2). The initial deposits determined on fruits and leaves two hours after application were 3.163 and $28.261 \mathrm{mg} / \mathrm{kg}$, respectively. These amounts were decreased to 1.854 and $21.443 \mathrm{mg} / \mathrm{kg}$ one day after treatment recording loss rates of $41.39 \%$ and $24.13 \%$. Chlorpyrifos residues in and on okra fruits and leaves were decreased gradually to reach $0.829,13.670 ; 0.430,9.532 ; 0.085,4.180 ; 0.011,1.053$ an $0.006,0.462 \mathrm{mg} / \mathrm{kg}$ indicating loss percentages of $73.79,51.63 ; 86.41,66.27 ; 97.31,85.21 ; 99.65$, 96.27 and $99.81,98.37 \%$ after 3, 6, 9, 12 and 15 days of spraying, respectively. The $t_{1 / 2}$ values were 1.58 and 2.57 days from the treatment with degradation rates of 0.43661 and 0.269451 for the okra fruits and leaves, respectively. These figures indicated that the insecticide chlorpyrifos was degraded higher in fruits than that leaves.

Results in the Tables (1 and 2) revealed that okra leaves remained higher initial amounts than fruits by about $382.52 \%$ and $893.48 \%$ of thiamethoxam and chlorpyrifos, respectively. This finding may be due to insecticide chemical structure and the effect of nature of the recipient surface (i.e., morphological and chemical aspects) on retention of residues, also leaves have a large surface per weight unit in comparison to fruits. 
Table 2: Residues of chlorpyrifos detected in okra fruits and leaves.

\begin{tabular}{|c|c|c|c|c|c|c|}
\hline $\begin{array}{c}\text { Days after } \\
\text { treatment }\end{array}$ & $\begin{array}{c}\text { Fruits } \\
\text { residues } \\
(\mathbf{m g} / \mathbf{k g})\end{array}$ & $\begin{array}{c}\text { Dissipation } \\
\mathbf{\%}\end{array}$ & Persistence & $\begin{array}{c}\text { Leaves } \\
\text { residues } \\
(\mathbf{m g} / \mathbf{k g})\end{array}$ & $\begin{array}{c}\text { Dissipation } \\
\mathbf{\%}\end{array}$ & Persistence \\
\hline $\begin{array}{c}\text { Initial } \\
(2 \mathrm{hrs})\end{array}$ & 3.163 & - & 100.00 & 28.261 & - & 100.00 \\
\hline 1 & 1.854 & 41.39 & 58.61 & 21.443 & 24.13 & 75.87 \\
\hline 3 & 0.829 & 73.79 & 26.21 & 13.670 & 51.63 & 48.37 \\
\hline 6 & 0.430 & 86.41 & 13.59 & 9.532 & 66.27 & 33.73 \\
\hline 9 & 0.085 & 97.31 & 2.69 & 4.180 & 85.21 & 14.79 \\
\hline 12 & 0.011 & 99.65 & 0.35 & 1.053 & 96.27 & 3.73 \\
\hline 15 & 0.006 & 99.81 & 0.19 & 0.462 & 98.37 & 1.63 \\
\hline $\mathrm{K}$ & 0.43661 & & & 0.26945 & & \\
\hline $\mathrm{t}^{1 / 2}$ & 1.59 & & & 2.57 & & \\
\hline
\end{tabular}

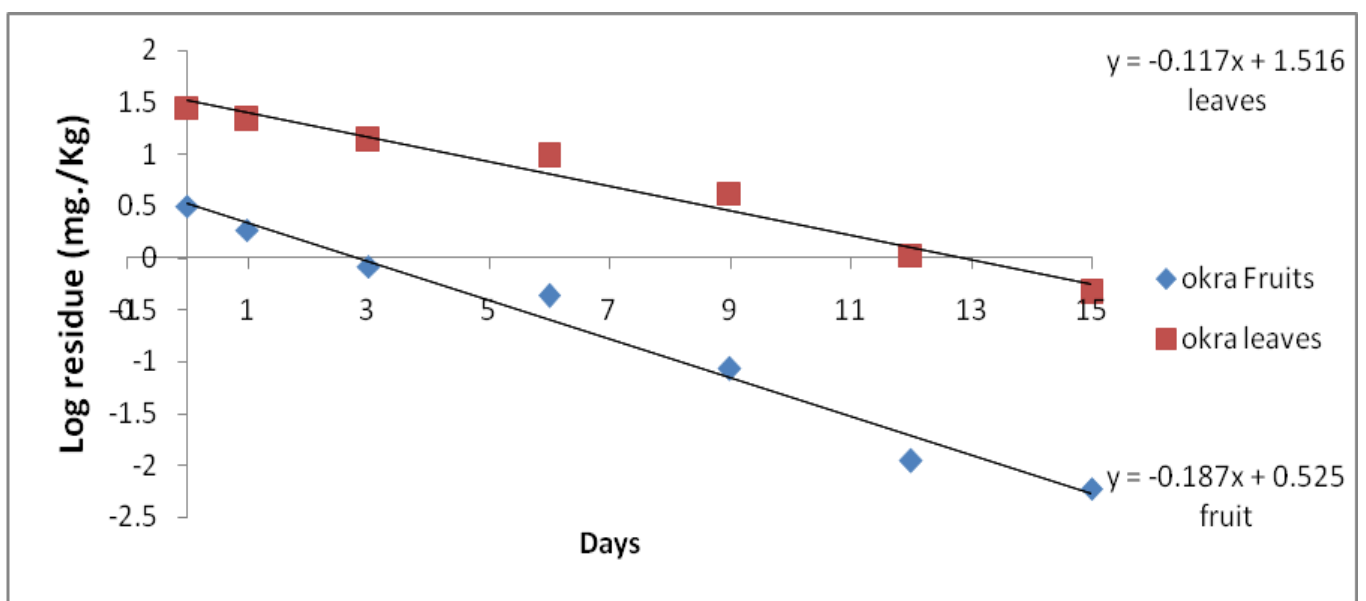

Figure (2): Log. residue - day regression line of chlorpyrifos in okra fruits and leaves.

3- Effect of washing and parboil on thiamethoxam and chlorpyrifos residues 
Data in Table (3) clearly showed the effect of home processing like washing with tap water and boiling on the reduction of thiamethoxam and chlorpyrifos residues in okra fruits. Results indicated that during the first four

Table 3: Effect of washing and boiling on thiamethoxam and chlorpyrifos residues contaminated okra fruits.

\begin{tabular}{|c|c|c|c|c|c|c|}
\hline \multirow{2}{*}{$\begin{array}{c}\text { Days after } \\
\text { treatment }\end{array}$} & \multicolumn{3}{|c|}{ Thiamethoxam } & \multicolumn{3}{c|}{ Chlorpyrifos } \\
\cline { 2 - 7 } & $\begin{array}{c}\text { Unwashed } \\
\text { fruits }\end{array}$ & $\begin{array}{c}\text { Washed } \\
\text { fruits }\end{array}$ & Boiling & $\begin{array}{c}\text { Unwashed } \\
\text { fruits }\end{array}$ & $\begin{array}{c}\text { Washed } \\
\text { fruits }\end{array}$ & Boiling \\
\hline $\begin{array}{c}\text { Initial } \\
(2 \mathrm{hrs})\end{array}$ & 0.532 & 0.286 & 0.058 & 3.163 & 2.486 & 0.395 \\
& & $(46.24)$ & $(89.09)$ & & $(21.40)$ & $(87.51)$ \\
\hline 1 & 0.393 & 0.309 & 0.083 & 1.854 & 1.508 & 0.258 \\
& & $(21.37)$ & $(78.88)$ & & $(18.66)$ & $(84.63)$ \\
\hline 3 & 0.218 & 0.176 & 0.055 & 0.829 & 0.732 & 0.124 \\
& & $(19.49)$ & $(74.77)$ & & $(11.70)$ & $(85.04)$ \\
\hline 6 & 0.130 & 0.118 & 0.029 & 0.430 & 0.396 & 0.058 \\
& & $(9.23)$ & $(77.69)$ & & $(7.91)$ & $(86.51)$ \\
\hline
\end{tabular}

Number between brackets indicate the \% Dissipation

samples ( 2 hrs, 1, 3 and 6 days after spraying); the removal percentages of thiamethoxam residues by washing ranged between 9.39 and $46.23 \%$. While the removal percentages due to boiled treated okra fruits for 2 min ranged from 74.77 to $89.09 \%$ while, the removal percentages ranged between $5.88-21.40$ and $84.63-87.51 \%$ by washing and boiling for 2 minutes, respectively in case of chlorpyrifos

Curiously enough to note that in case of the insecticide thiamethoxam the highest removal percentage by washing with tap water was recorded after 2 hours of application (46.24\%) then dropped to be $21.37 \%$ after one day. This phenomenon is due to the high solubility in water and the systemic action of thiamethoxam that rapidly taken up into the plant and transported acropetally in the xylem. (MacBean, 2012).

Data in Tables (2 and 3) reveled that unwashed and washed okra fruits treated with chlorpyrifos could be used safely for human consumption after 6 days of treatment which comparing the residues at 6 days with the maximum residues limits $(0.5 \mathrm{mg} / \mathrm{kg})$ recorded by EU Pesticides database - European 
Commission, while no safety interval was needed for okra fruits if the fruits were boiled for 2 minutes. While in case of thiamethoxam the boiled of treated fruits did not alter the PHI values (Tables, 1 and 3).

The finding results concerning with the residues of thiamethoxam and chlorpyrifos in and on okra fruits are in harmony with those obtained by Randhawa et al. (2007) found that the decreased of chlorpyrifos residues ranged for $12 \%$ to $48 \%$ during boiling of different vegetables with water. Kumari (2008) reported that washing of brinjal, cauliflower and okra reduced the residues of OP insecticides by $77 \%$ in brinjal, followed by $74 \%$ in cauliflower and $50 \%$ in okra. The same treated was observed by boiling process where maximum (100\%) reduction of insecticides in brinjal followed by $92 \%$ in cauliflower and $75 \%$ in okra.

The half-life of thiamethoxam was 2.3 days in spinach treated by $25 \%$ thiamethoxam suspension concentration applied at $180 \mathrm{~g} / \mathrm{ha}$ solution and the residues in spinach was $0.55 \mathrm{mg} / \mathrm{kg}$ after 3 days (Bin et al, 2009). Ahmed (2010) found that the removal percentages of pirimiphos-methyl on okra fruits ranged between $84.81-100.00 \%$ resulting of blenching the treated okra fruits. Sheikh et al. (2012) reported that blanching of okra fruits was more effective in eliminating pesticide residues as compared to tap water washing. Lozowicka and Jankowska (2014) stated that washing broccoli plants with tap water reduced chlorpyrifos residues by $42.4 \%$. The blanching step decreased chlorpyrifos by $52 \%$ and the cooking resulted in decreased of chlorpyrifos residues up to $61.6 \%$. Vemuri et al. (2014) found that running tap water washing reduced the residues of OP insecticides in tomato (Dimethoate, Methylparathion, Quinolphos, Endosulfan and Profenophos) by $47.07 \%$ to $53.00 \%$. Andrade et al. (2015) stated that the most imported mechanism that may be lead to the possible residue alteration during household washing processes is the dissolution, which is related the water solubility of the pesticide residues. Also, the penetration is a dynamic process that may control the fate of a pesticide residue during washing.

Other factors may further affect the pesticide dissolution mechanism, such as the type of formulation applied, temperature and initial concentration of the pesticide residue on commodity, pesticide partition coefficient (Kow), ionic strength and $\mathrm{pH}$ of the aqueous media. Sleem (2015) reported that broad bean pods and green bean pods had considerable amounts of thiamethoxam residues $(0.495-0.002$ and $0.872-0.01 \mathrm{mg} / \mathrm{kg})$, respectively depending on the time from 
insecticide application. Also, the same author found that cooking process reduced the residues of thiamethoxam from 0.28 to $0.052 \mathrm{mg} / \mathrm{kg}$ (81.43\% reduction) and from 0.442 to $0.142 \mathrm{mg} / \mathrm{kg}(67.87 \%$ reduction) in broad bean pods and green bean pods, respectively. Ramadan et al. (2016) stated that the half-life in days were 2.5 and 6.3 for chlorpyrifos and thiamethoxam in tomato. The PHI values were 1.5 and 10 days for tomatoes treated with chlorpyrifos and thiamethoxam, respectively.

\section{4- Effect of thiamethoxam and chlorpyrifos residues on some quality attributes}

The quality of okra fruits and its validity for edible use by consumer depends on its contamination with pesticide residues. Thus, the possible effects of thiamethoxam and chlorpyrifos residues on okra fruits quality were determined and presented in Tables (4 and 5).

Data in Table (4) showed the residue effects of thiamethoxam and chlorpyrifos on total soluble sugar $\%$, glucose $\mathrm{mg} / 100 \mathrm{~g}$, acidity $\%$, total soluble solids $\%$, ascorbic acid $\mathrm{mg} / 100 \mathrm{~g}, \beta$-carotene $\%$ and dry matter $\%$ of fresh okra fruits. The mean value of total soluble sugar, glucose, acidity, total soluble solids, $\beta$-carotene, dry matter and protein content \% contents of thiamethoxam and chlorpyrifos treated okra fruits were decreased during the tested period (15 days) comparing with untreated fruits. The corresponding figures were 4.767, 4.301, $4.686 ; 22.322$, 21.735, 21.963; 4.123, 4.421, 4.536; 4.016, 3.643, 3.921; 6.000, $5.645,5.500 ; 16.920,15.996,16.110$ and $9.423,8.911,9.413$ for the control, thiamethoxam and chlorpyrifos, respectively. In case of ascorbic acid thiamethoxam reduced the mean value $(23.11 \mathrm{mg} / 100 \mathrm{~g})$, while chlorpyrifos increased this amount to be $23.726 \mathrm{mg} / 100 \mathrm{~g}$ comparing with the control 23.206 $\mathrm{mg} / 100 \mathrm{~g}$. Also, data revealed that the reduction of these quality attributes was more pronounced with thiamethoxam than chlorpyrifos. This finding may be due to the ability of thiamethoxam to have a good systemic effect. Although thiamethoxam is well documented as systemic insecticide (MacBean, 2012) such systemic effect is result from the higher penetration of thiamethoxam through the okra fruits, where it acts on certain biochemical system.

The decreasing of total soluble sugars, glucose and T.S.S in treated fruits may be due to the decreasing effects of the two tested insecticides thiamethoxam and chlorpyrifos on the carbohydrate hydrolyzing enzymes (invertase, trehase and amylase). 
The decreasing effects of thiamethoxam and chlorpyrifos on dry matter in treated okra fruits compared with untreated fruits may be due to the reduction in concentrating the fruit juice because higher remained of water by decreasing the respiration rates resulting lack accumulation of different solutes in cell vacuoles.

Table 4: Effect of thiamethoxam and chlorpyrifos residues on some quality attributes of okra fruits.

\begin{tabular}{|c|c|c|c|c|}
\hline $\begin{array}{c}\text { Quality } \\
\text { parameters }\end{array}$ & $\begin{array}{l}\text { Days after } \\
\text { spraying }\end{array}$ & $\begin{array}{l}\text { Untreated } \\
\text { fruits }\end{array}$ & $\begin{array}{c}\text { Treated } \\
\text { fruits with } \\
\text { thiamethoxam }\end{array}$ & $\begin{array}{c}\text { Treated } \\
\text { fruits with } \\
\text { chlorpyrifos }\end{array}$ \\
\hline \multirow{4}{*}{$\begin{array}{c}\text { Total soluble sugar } \\
\%\end{array}$} & 6 & $5.500 \mathrm{a}$ & $4.125 \mathrm{c}$ & $5.075 \mathrm{~b}$ \\
\hline & 9 & $3.945 \mathrm{~b}$ & $4.465 \mathrm{a}$ & $4.425 \mathrm{a}$ \\
\hline & 15 & $4.856 \mathrm{a}$ & $4.365 \mathrm{~b}$ & $4.560 \mathrm{~b}$ \\
\hline & Means & $4.767 a$ & $4.318 \mathrm{~b}$ & $4.686 \mathrm{a}$ \\
\hline \multirow{4}{*}{$\begin{array}{l}\text { Glucose } \\
\mathrm{mg} / 100 \mathrm{~g}\end{array}$} & 6 & $23.106 \mathrm{a}$ & $21.716 \mathrm{~b}$ & $21.705 \mathrm{~b}$ \\
\hline & 9 & $21.770 \mathrm{c}$ & $21.935 \mathrm{a}$ & $21.815 \mathrm{~b}$ \\
\hline & 15 & $22.090 \mathrm{~b}$ & $21.555 \mathrm{c}$ & $22.370 \mathrm{a}$ \\
\hline & Means & 22.322 a & $21.735 \mathrm{c}$ & $21.963 \mathrm{~b}$ \\
\hline \multirow{4}{*}{$\begin{array}{c}\text { Acidity } \\
\%\end{array}$} & 6 & $3.560 \mathrm{c}$ & $4.230 \mathrm{~b}$ & $4.605 \mathrm{a}$ \\
\hline & 9 & $4.535 \mathrm{a}$ & $4.475 \mathrm{~b}$ & $4.460 \mathrm{~b}$ \\
\hline & 15 & $4.276 \mathrm{~b}$ & $4.560 \mathrm{a}$ & $4.545 \mathrm{a}$ \\
\hline & Means & $4.123 \mathrm{c}$ & $4.421 \mathrm{~b}$ & $4.536 \mathrm{a}$ \\
\hline \multirow{4}{*}{$\begin{array}{c}\text { Total soluble solid } \\
\text { (T.S.S.) } \\
\%\end{array}$} & 6 & $4.450 \mathrm{a}$ & $3.646 \mathrm{~b}$ & $3.750 \mathrm{~b}$ \\
\hline & 9 & $3.555 \mathrm{c}$ & $3.750 \mathrm{~b}$ & $3.945 \mathrm{a}$ \\
\hline & 15 & $4.045 \mathrm{~b}$ & $3.5350 \mathrm{a}$ & $4.070 \mathrm{a}$ \\
\hline & Means & $4.016 \mathrm{a}$ & $3.643 \mathrm{c}$ & $3.921 \mathrm{~b}$ \\
\hline \multirow{4}{*}{$\begin{array}{l}\text { Ascorbic acid } \\
\mathrm{mg} / 100 \mathrm{~g}\end{array}$} & 6 & $25.260 \mathrm{a}$ & $21.350 \mathrm{c}$ & $23.540 \mathrm{~b}$ \\
\hline & 9 & $21.810 \mathrm{c}$ & $23.740 \mathrm{~b}$ & $24.085 \mathrm{a}$ \\
\hline & 15 & $22.550 \mathrm{c}$ & $24.255 \mathrm{a}$ & $23.5550 \mathrm{~b}$ \\
\hline & Means & 23.206 b & 23.115 c & 23.726 a \\
\hline \multirow[t]{4}{*}{$\beta$-carotene $\%$} & 6 & $7.160 \mathrm{a}$ & $5.860 \mathrm{~b}$ & $5.458 \mathrm{c}$ \\
\hline & 9 & $5.665 \mathrm{~b}$ & $6.040 \mathrm{a}$ & $6.095 \mathrm{a}$ \\
\hline & 15 & $5.175 \mathrm{a}$ & $5.035 \mathrm{~b}$ & $4.955 \mathrm{c}$ \\
\hline & Means & $6.000 \mathrm{a}$ & $5.645 \mathrm{~b}$ & $5.500 \mathrm{c}$ \\
\hline \multirow[t]{4}{*}{ Dry matter\% } & 6 & $15.170 \mathrm{c}$ & $17.225 \mathrm{a}$ & $16.345 \mathrm{~b}$ \\
\hline & 9 & $17.155 \mathrm{~b}$ & $15.835 \mathrm{c}$ & $17.265 \mathrm{a}$ \\
\hline & 15 & $18.436 \mathrm{a}$ & $14.930 \mathrm{~b}$ & $14.720 \mathrm{c}$ \\
\hline & Means & $16.920 \mathrm{a}$ & $15.996 \mathrm{c}$ & $16.110 \mathrm{~b}$ \\
\hline
\end{tabular}




\begin{tabular}{|l|c|c|c|c|}
\hline Protein\% & 6 & $10.870 \mathrm{a}$ & $9.275 \mathrm{c}$ & $9.620 \mathrm{a}$ \\
\cline { 2 - 5 } & 9 & $8.625 \mathrm{c}$ & $9.025 \mathrm{~b}$ & $9.625 \mathrm{a}$ \\
\cline { 2 - 5 } & 15 & $8.776 \mathrm{a}$ & $8.435 \mathrm{a}$ & $8.995 \mathrm{~b}$ \\
\cline { 2 - 5 } & Means & $\mathbf{9 . 4 2 3} \mathbf{a}$ & $\mathbf{8 . 9 1 1 ~ b}$ & $\mathbf{9 . 4 1 3} \mathbf{a}$ \\
\hline
\end{tabular}

\section{5- Effect of thiamethoxam and chlorpyrifos residues on some trace and nutrients elements.}

Concerning the trace and nutrients elements, data in Table (5) showed that thiamethoxam significantly reduced the mean values of $\mathrm{N} \%, \mathrm{P} \%, \mathrm{~K} \%$, $\mathrm{Mn} \%$ and $\mathrm{Ca} \%$ in treated okra fruits comparing with the untreated fruits. The mean values of $\mathrm{Fe} \%$ and $\mathrm{Zn} \%$ were significantly increased in the fruit treated with thiamethoxam comparing with untreated one. While in case of chlorpyrifos it was found that the mean levels of $\mathrm{N} \%, \mathrm{P} \%, \mathrm{~K} \%, \mathrm{Fe} \mathrm{mg} / \mathrm{kg}, \mathrm{Ca} \%$ were significantly reduced in treated fruit when compared to the untreated samples. The mean values of $\mathrm{Mn} \mathrm{mg} / \mathrm{kg}$ and $\mathrm{Zn} \mathrm{mg} / \mathrm{kg}$ were significantly increased in the fruits treated with thiamethoxam comparing with untreated one. Data in the same table revealed that thiamethoxam treatments gave higher reduction effect in the levels of $\mathrm{P} \%, \mathrm{~K} \%, \mathrm{Ca} \%$ in okra fruits when compared with fruit treated with chlorpyrifos. The decreasing in the tested elements may be due to reduction effects of the two tested insecticide on the ability of okra plants to absorb the trace nutrient elements from the soil. In this respect, Rouchaud et al. (1983) found that the percentage of Birlane, Nexion and Dyeonate generally increased the free sugar concentration of summer carrots. Habiba et al. (1992) reported that the organophosphorus insecticide profenofos residues slightly decreased the glucose content in potatoes and ascorbic acid was elevated by $20 \%$ in profenofos treated potatoes. Ismail et al. (1993) reported the same in tomatoes. Radwan (1995) found that pirimiphos-methyl residues appeared to have significant effects on total soluble sugars, ascorbic acid, Iron and calcium levels of tomato fruits and breoad bean seeds. Significant effects were also noticed on a $\mathrm{pH}$ values in bean seeds and manganes content in tomato after treated with chlorpyrifos-methyl and pirimiphos-methyl.

Chlorpyrifos-methyl exhibited a significant increased in crude protein in bean seeds, whereas significant decreased on $\beta$-carotene in tomato fruits was noticed. Habiba and Ismail 1998 found that dicofol treated in strawberries decreased the total soluble solids, glucose, ascorbic acid and protein content 
after 2 weeks of treatment, but the normal value were restored at the third week following application. Salem (2011) reported that the elements N, P, K, Mg, Fe, $\mathrm{Mn}, \mathrm{Na}$ and $\mathrm{Ca}$ were reduced in wheat treated with malathion.

Table 5: Effect of thiamethoxam and chlorpyrifos residues on some trace and elements of okra fruits.

\begin{tabular}{|c|c|c|c|c|}
\hline Elements & $\begin{array}{c}\text { Days } \\
\text { after spraying }\end{array}$ & $\begin{array}{l}\text { Untreated } \\
\text { fruits }\end{array}$ & $\begin{array}{c}\text { Treated } \\
\text { fruits with } \\
\text { thiamethoxam }\end{array}$ & $\begin{array}{c}\text { Treated } \\
\text { fruits with } \\
\text { chlorpyrifos }\end{array}$ \\
\hline \multirow{4}{*}{$\begin{array}{l}\mathrm{N} \\
\%\end{array}$} & 6 & $1.740 \mathrm{a}$ & $1.486 \mathrm{~b}$ & $1.540 \mathrm{c}$ \\
\hline & 9 & $1.380 \mathrm{c}$ & $1.445 \mathrm{~b}$ & $1.540 \mathrm{a}$ \\
\hline & 15 & $1.405 \mathrm{~b}$ & $1.350 \mathrm{c}$ & $1.440 \mathrm{a}$ \\
\hline & Means & $1.508 \mathrm{a}$ & $1.427 \mathrm{~b}$ & $1.506 \mathrm{a}$ \\
\hline \multirow{4}{*}{$\begin{array}{l}\mathrm{P} \\
\%\end{array}$} & 6 & $0.764 \mathrm{a}$ & $0.545 \mathrm{c}$ & $0.676 \mathrm{~b}$ \\
\hline & 9 & $0.666 \mathrm{a}$ & $0.653 \mathrm{~b}$ & $0.552 \mathrm{c}$ \\
\hline & 15 & $0.682 \mathrm{a}$ & $0.623 \mathrm{c}$ & $0.633 \mathrm{~b}$ \\
\hline & Means & 0.704 a & $0.607 \mathrm{c}$ & $0.620 \mathrm{~b}$ \\
\hline \multirow{4}{*}{$\begin{array}{l}\mathrm{K} \\
\%\end{array}$} & 6 & $3.618 \mathrm{a}$ & $2.090 \mathrm{~b}$ & $2.362 \mathrm{~b}$ \\
\hline & 9 & $2.195 \mathrm{a}$ & $2.335 \mathrm{a}$ & $2.180 \mathrm{a}$ \\
\hline & 15 & $2.250 \mathrm{a}$ & $2.075 \mathrm{c}$ & $2.240 \mathrm{~b}$ \\
\hline & Means & 2.687 a & $2.166 \mathrm{~b}$ & $2.260 \mathrm{~b}$ \\
\hline \multirow{4}{*}{$\begin{array}{c}\mathrm{Fe} \\
\mathrm{mg} / \mathrm{kg}\end{array}$} & 6 & $77.100 \mathrm{~b}$ & $85.546 \mathrm{a}$ & $89.535 \mathrm{a}$ \\
\hline & 9 & $86.435 \mathrm{~b}$ & $95.620 \mathrm{a}$ & $83.113 \mathrm{~b}$ \\
\hline & 15 & $96.310 \mathrm{~b}$ & $105.113 \mathrm{c}$ & $75.935 \mathrm{a}$ \\
\hline & Means & 86.615 b & $95.460 \mathrm{a}$ & 82.861 c \\
\hline \multirow{4}{*}{$\begin{array}{c}\mathrm{Mn} \\
\mathrm{mg} / \mathrm{kg}\end{array}$} & 6 & $60.126 \mathrm{c}$ & $75.106 \mathrm{~b}$ & $78.535 \mathrm{a}$ \\
\hline & 9 & $83.555 \mathrm{a}$ & $72.865 \mathrm{c}$ & $79.865 \mathrm{~b}$ \\
\hline & 15 & $84.095 \mathrm{~b}$ & $77.150 \mathrm{a}$ & $82.150 \mathrm{c}$ \\
\hline & Means & $75.925 \mathrm{~b}$ & $75.040 \mathrm{c}$ & 80.183 a \\
\hline \multirow{4}{*}{$\begin{array}{l}\mathrm{Ca} \\
? ? ?\end{array}$} & 6 & $0.855 \mathrm{a}$ & $0.670 \mathrm{c}$ & $0.760 \mathrm{~b}$ \\
\hline & 9 & $0.745 \mathrm{~b}$ & $0.754 \mathrm{a}$ & $0.640 \mathrm{c}$ \\
\hline & 15 & $0.694 \mathrm{~b}$ & $0.690 \mathrm{~b}$ & $0.785 \mathrm{a}$ \\
\hline & Means & 0.765 a & $0.704 \mathrm{c}$ & 0.728 b \\
\hline \multirow{3}{*}{$\begin{array}{c}\mathrm{Zn} \\
\mathrm{mg} / \mathrm{kg}\end{array}$} & 6 & $22.216 \mathrm{c}$ & $25.746 \mathrm{~b}$ & $28.346 \mathrm{a}$ \\
\hline & 9 & $27.345 \mathrm{~b}$ & $25.835 \mathrm{c}$ & $28.265 \mathrm{a}$ \\
\hline & 15 & $28.405 \mathrm{a}$ & $26.735 \mathrm{~b}$ & $27.155 \mathrm{~b}$ \\
\hline
\end{tabular}




\begin{tabular}{|l|l|l|l|l|}
\hline & Means & 25.988 c & 26.105 b & 27.922 a \\
\hline
\end{tabular}

Conclusively, okra fruits treated with the neonicotonoied insecticide thiamethoxam needed a long interval to reach the maximum residue limits. Also, obtained data revealed that its residues were more effective in some quality attributes as well as some trace and nutrient elements than that the organphosphorus chlorpyrifos. Therefore, special care must be given to the use of this insecticide especially at the mature stage of okra plants.

\section{REFERENCES}

Ahmed, M. A. A. (2010). Studies on residues of certain pesticides in some vegetable crops. M. Sc. Thesis. Fac. of Agric., Zagazig Univ.

Amro, M. A.; G. H. Abd El-Rahim; H. H. Mahmoud and A. A. Abd ElRaheem (2013). Effect of intercropping systems on the incidence of some sap sucking and fruit pests infesting okra and roselle plantations. Ass. Univ. Bull. Environ. Res., (16) 2: ??-??

Anastassiades, M.; S. J. Lehotay; D. Stajnbaher and F. Schenck (2003). Fast and easy multiresidue method employing acetonitrile extraction/partitioning and "dispersive solid-phase extraction" for the determination of pesticide residues in produce. J. AOAC. Int., 86: 412-431.

Andrade, G. C; S. H. Monteiro; J. G. Francisco; L. A. Figueiredo; A. A. Rocha and V. L. Tornisielo (2015). Effects of Types of Washing and Peeling in Relation to Pesticide Residues in Tomatoes. J. Braz. Chem. Soc., 26 (10): ???-???

Antunes-Kenyon, S. E. and G. Kennedy (2001). Thiamethoxam, a new active ingredient review, for the Massachusetts Pesticide Board Subcommittee. Massachusetts Pesticide Bureau, Department of Food and Agriculture, $37 \mathrm{pp}$.

AOAC (1984). Association of official Analytical Chemists . Official methods of analysis, $19^{\text {th }}$ ed., Washington, D.C.

Bethke, J. A.; M. J. Blua and R. A. Redak (2001). Effect of selected insecticides on Homalodisca coagulate (Homoptera: Cicadelidae) and transmission of oleander leaf scorch in a greenhouse study. J. Economic Entomology, 94: 1031 - 1036. 
Ben-Amotz, A. B. and M. Avron (1983). On the factors which determine massive $\beta$-carotene accumulation in the halo tolerant alge Dunaliella bardawil. Plant. Physiol., 72: 593-597.

Bin, L.; G. Dong-liang; M. Jiang-sheng; Z. Shan-eang and W. Yu-tao (2009). Residue detection and degradation of thiamethoxam in spinach. Journal of Agrochem.; 9 ?????

Dubois, M., K. A. Giles; J. K. Hamilton; P. A. Robers and F. Smith (1956). Colorimetric method for determination of sugar and related substance. Analytical Chemistry., 28: 350-356.

Evenhuis, B. and P. W. Waard (1980). Principle and practices in plant analysis F.A.O. Soils Bell., 38 (1) 152-163.

Gomaa, E.A.A. and M.H. Belal (1975). Determination of dimethoate residues in some vegetables and cotton plant. Zagazig J Agric Res., 2: 215-219.

Ramadan, G.; M. Shawir; A. El-bakary; and S. Abdelgaleil (2016). Dissipation of four insecticides in tomato fruit using high performance liquid chromatography and QuEChERS methodology. Chilean J. Agri. Research, 76 (11): $129-133$.

Grubben, G.J.H. and O.A. Denton (2004). Plant Resources of Tropical Africa 2. Nordic Journal of Botany, 23: 298

Habiba, R.A.; H.M. Ali and S. M. M. Ismail (1992). Biochemical effects of profenofos residues in potatoes. J. Agric. Food Chem., 40: 1852-1855.

Habiba, R.A. and M.M. Ismail (1998). Biochemical effects of Dicofol in strawberries. Egypt. J. Appl. Sci., 13 (7):257-273.

Hegazy, M. E. A.; Afify, A. M. R.; Hamama, A. A. and El-Refahey, T. F. A. (2006). Persistence and behavior of certain pesticide residues on tomato fruits in relation to processing and biochemical constituents of fruits. Egypt. J. Agric. Res., 84 (3): 853-865.

Ismail, S. M.; H. M. Ali and R. A. Habiba (1993). GC-ECD and GC-M Sanalysis of profenofos residues and biochemical effects in tomatoes and tomato products. Journal of Agri. Food. Chem., 41:610-615.

Jackson, M. L. (1967). Soil Chemical Analysis Prentice. Hall Inc. Englewood cliffs N.J. Library of congress, USA.

Kumari, B. (2008). Effect of household processing on reduction of pesticide residues in vegetables. J. Agric. Biol. Sci., 3 (4): 46-51. 
Kumari, B.; V. K. Madan; R. Kumar and T. S. Kathpal (2002). Monitoring of seasonal vegetables for pesticide residues. Environ. Monit Assess; 74: 263-70.

Lozowicka, B. and M. Jankowska (2014). Effects of technological processing on levels of fungicide and insecticide residues in broccoli. $2^{\text {nd }}$ International Conf. Res. Sci. Engineering Technol., March 21 - 22 Dubai (UAE).

MacBean, C. (2012). The Pesticide. Manual version 5.2, fifteenth Ed. chlorpyrifos (157) and thiamethoxam (840).

Mahal, M. S.; L. S. Brar; R. Singh and B. Singh (1994). Influence of varying magnitude of jassid injury on seed yield of okra and economics of its control. J. Insect Sci. , 7: 129-132.

Manson, G.; M. Rancati and D. Bosco (2000). The effect of Thiamethoxam a second generation neonicotinoid in preventing transmission of tomato yellow leaf curl geminivirus (TYLCV) by the whitefly Bemisia tabaci (Gennadius). Crop protection, 19 (7): $473-479$.

Radwan, M.A.; M.M. Youssef; A. Abd-El-All; G.L. El-Henawy and A. Marei (1995). Residues levels of pirimiphos-methyl and chlorpyrifos-methyl on tomato and faba bean plants in relation to their impact on some internal quality parameters. Alex. Sci. Exch., 16 (3): 389-404.

Randhawa, M. A.; F. M. Anjum; A. Ahmed and M. S. Randhawa (2007). Field incurred chlorpyrifos and 3,5,6-trichloro-2-pyridinol residues in fresh and processed vegetables. Food Chem., 103: 1016-1023

Rouchaud, J.; C. Moons and J. A. Meyer (1983). Effects of selected insecticides and herbicides on free sugar contents of carrots. J. Agric. Food Chem. (31): $206-210$.

Salem, R. E. M. (2011). Side effects of certain pesticides on the relationship between plant and soil. Ph. D. Thesis. Fac. of Agric., Zagazig Univ.

Sattler, C.; H. Kächele and G.Verch (2007). Assessing the intensity of pesticide use in agriculture. Agriculture, Ecosystems and Environment; 119: 99-304.

Sleem, F. M. A. (2015). Persistence of some pesticides in and on some crops. Ph. D. Thesis. Fac. of Agric., Zagazig Univ.

Sheikh, S. A.; S. M. Nizamani; A. A. Jamali; A. A. Panhwar; M. J.Channa and B. N. Mirani (2012). Removal of Pesticide Residues from Okra Vegetable through Traditional Processing. J. Basic \& Applied Sci., 8: 79-84 
Steel, R. C. D. and J. H. Torrie (1980). Principles and Procedures of Statistics: A Biomatrical Approach, Second ed. Mc-Graw Hill Kogakusha Ltd., pp. 633.

Vemuri, S. B.; C. S. Rao; R. Darsi; R. A. Harinatha; M. Aruna; B. Ramesh and S. Swarupa (2014). Methods for removal of pesticide residues in tomato. Food Science and Technology, 2(5): 64-68.

\section{متبقيات الثياميثوكسام والكلوربيريفوس فى الباميا وعلاقة ذلك بتأثير هما

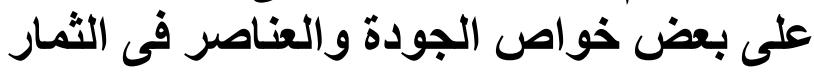

$$
\text { قلى عطا على شلبحى }
$$

أجريت هذه الدر اسة لتحديد بقايا اثنين من المبيدات الحشرية على نباتات البامية. حيث

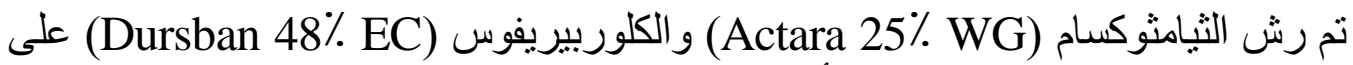

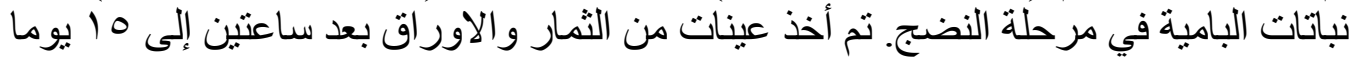
بعد الرش. و إستخدم طريقة كويتشرز لإستخلاص وتتفية العينات وتم تقدير المتبقى باستخدام

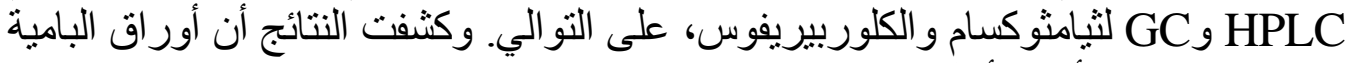

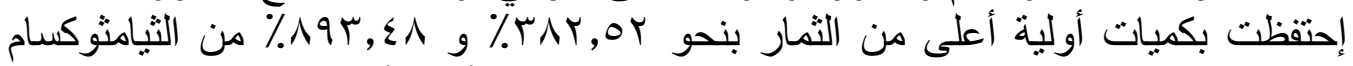

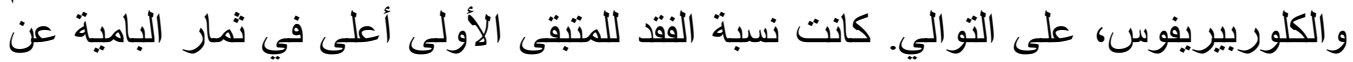

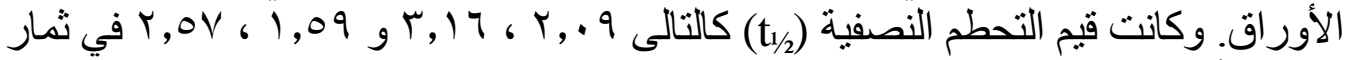

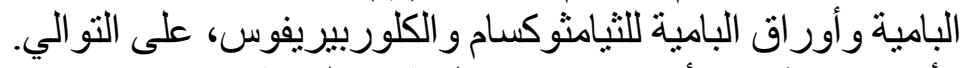

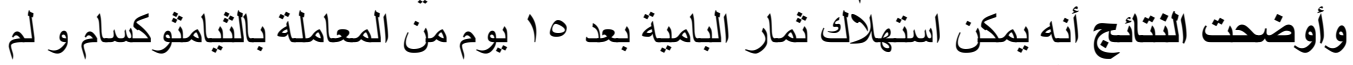

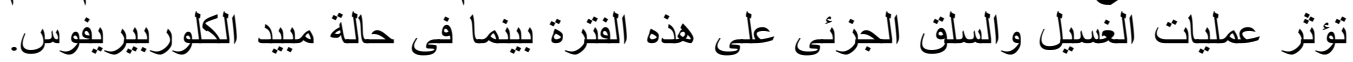

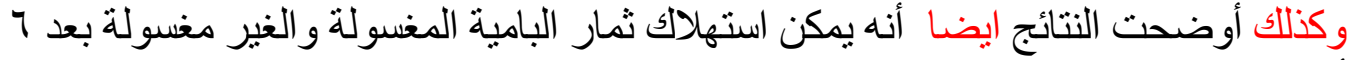
أيام ولا توجد فترة انتظار للاستهلاك الادمى بعد اجراء السلق الجزئى للثمار المعاملة بمبيد

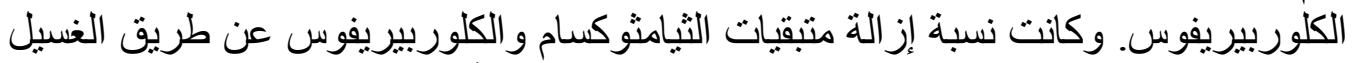

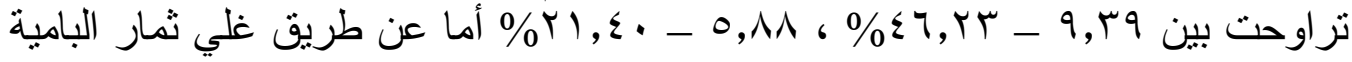

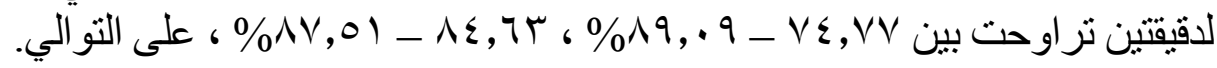


وكان لمتبقى الثيامثوكسام و الكلوربيريفوس تأثير معنوى فى انخفاض السكريات الكلية ، الجلوكوز ، الحموضة ، المواد الصلبة الذائبة ، حمض الأسكوربيك فئك ، و البيتا كاروتين ،

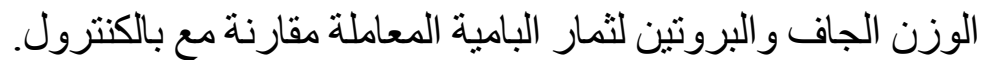

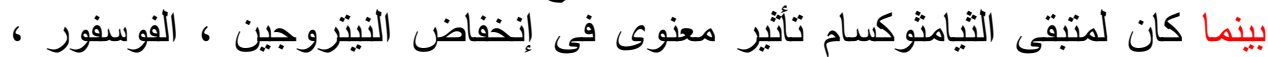

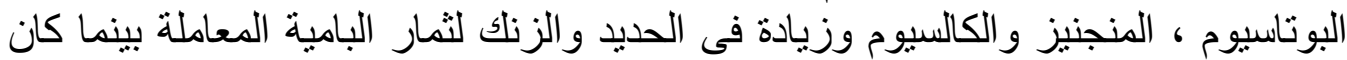

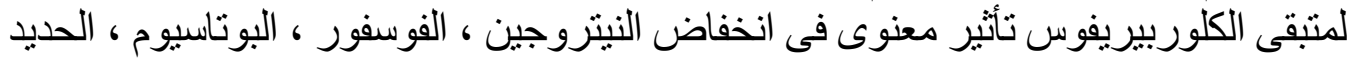

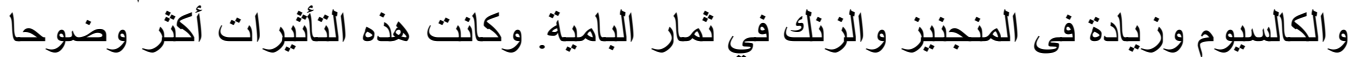
مع مبيد الثيامثوكسام ولذلك يجب لفت الانتباه الى خطورة إستخدام هذا المبيد وخاصة خلئ خلال طور نضج الثمار.

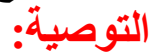

